\title{
Redescription of Rudakius ludbianaensis (Tikader, 1974) (Aranei: Salticidae), with notes on its synonymy and distribution
}

\author{
Переописание Rudakius ludbianaensis (Tikader, 1974) (Aranei: \\ Salticidae), с заметками от его синонимии и распространении
}

\author{
John T.D. Caleb ${ }^{1 *}$, Dhruv A. Prajapati ${ }^{2,3}$, Pir Asmati Ali ${ }^{4}$ \\ Ажкон Т.А. Кале6 ${ }^{1^{*}}$, Ахрув А. Праджапати ${ }^{2,3}$, П.А. Али \\ ${ }^{1}$ Centre for DNA Taxonomy, Zoological Survey of India, Prani Vigyan Bhawan, M-Block, New Alipore, Kolkata - 700053, West Bengal, \\ India. E-mail: caleb87woodgate@gmail.com \\ ${ }^{2}$ Research and Development Centre, Bharathiar University, Coimbatore - 641046, Tamil Nadu, India. \\ ${ }^{3}$ GEER Foundation, Indroda Nature Park, Gandhinagar - 382007, Gujarat, India. \\ ${ }^{4}$ Department of Zoology, Women University, Swabi, Pakistan. \\ * Corresponding author.
}

KEY WORDS: Araneae, India, Iran, jumping spider, distribution, synonyms, Pakistan.

КЛЮЧЕВЫЕ СЛОВА: Araneae, Индия, Иран, паук-скакунчик, распространение, синонимы, Пакистан.

ABSTRACT. Rudakius ludhianaensis (Tikader, 1974) is redescribed based on the type series and new materials from India and Pakistan. A detailed morphological description, diagnosis and illustrations of the copulatory organs are provided. The updated distribution range of the species is mapped. $R$. ludhianaensis is shown to be a senior synonym of two species names: Marpissa endenae Biswas et Biswas, 1992 syn.n. and Pseudicius admirandus Logunov, 2007 syn.n.

How to cite this article: Caleb J.T.D., Prajapati D.A., Ali P.A. 2019. Redescription of Rudakius ludhianaensis (Tikader, 1974) (Aranei: Salticidae), with notes on its synonymy and distribution // Arthropoda Selecta. Vol.28. No.3. P.417-423. doi: 10.15298/arthsel. 28.3.06

РЕЗЮМЕ. Rudakius ludhianaensis (Tikader, 1974) переописан на основе изучения типовой серии и новых материалов из Индии и Пакистана. Даны детальное морфологическое описание, диагноз и рисунки копулятивных органов. Исправленный ареал вида показан на карте. Показано, что R. ludhianaensis является старшим синонимом двух видовых названий: Marpissa endenae Biswas et Biswas, 1992 syn.n. и Pseudicius admirandus Logunov, 2007 syn.n.

\section{Introduction}

The genus Rudakius was erected by Prószyński in 2016, with Menemerus cinctus O. Pickard-Cambridge, 1885 being selected as its generotype. It currently includes seven species from Asia, all transferred from Pseudicius Simon, 1885 [WSC, 2018]: R. afghanicus (Andreeva, Hęciak et Prószyński, 1984), R. cinctus (O.
Pickard-Cambridge, 1885), R. ludhianaensis (Tikader, 1974), R. maureri (Prószyński, 1992), R. rudakii (Prószyński, 1992), R. spasskyi (Andreeva, Hęciak et Prószyński, 1984) and $R$. wenshanensis (He et $\mathrm{Hu}$, 1999). Like many other Indian salticids which were inadequately described and misplaced [Caleb, 2016; Caleb et al., 2017], R. ludhianaensis was poorly described in the genus Marpissa C.L. Koch, 1846 and cannot be identified by the original description or illustrations [Tikader, 1974]. In the present paper, we have provided a detailed redescription of $R$. ludhianaensis based on its type series, as well as on freshly collected specimens from new localities in India and Pakistan. Two species names - Marpissa endenae Biswas et Biswas, 1992 and Pseudicius admirandus Logunov, 2007 - are recognized as the junior synonyms of $R$. ludhianaensis.

Materials and methods

Live specimens were photographed using Nikon D60, DSLR. Specimens were preserved in 70\% alcohol and later examined using a Leica S8APO stereoscopic microscope. The type specimens at ZSI, Kolkata were examined and imaged using a Leica EZ4 HD stereomicroscope equipped with LAS EZ software. Male palps were detached and studied in detail. Female copulatory organs were excised using fine surgical blade and macerated in $10 \% \mathrm{KOH}$. All measurements are in $\mathrm{mm}$.

Abbreviations used in the text are as follows: AER anterior eye row, EFL - eye field length, PER - posterior eye row, RTA - retrolateral tibial apophysis.

The specimens are in the following museum and private collections: GJSP - Personal collection of Dhruv A. Prajapati (Gandhinagar, Gujarat, India); JCPC — Personal col- 


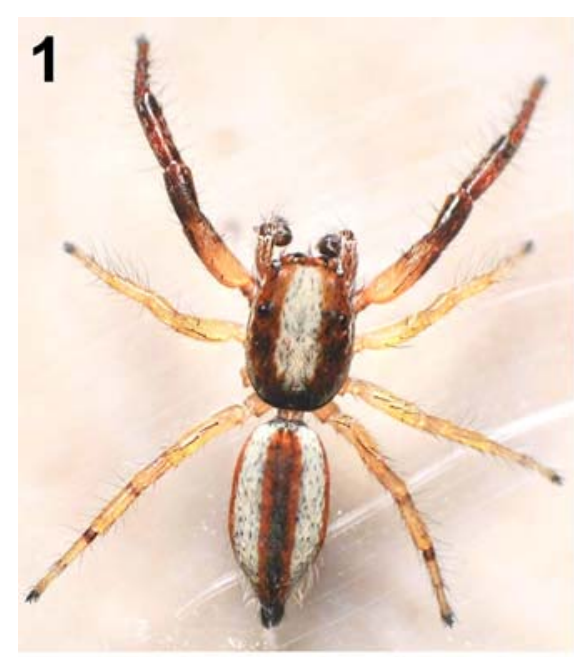

2

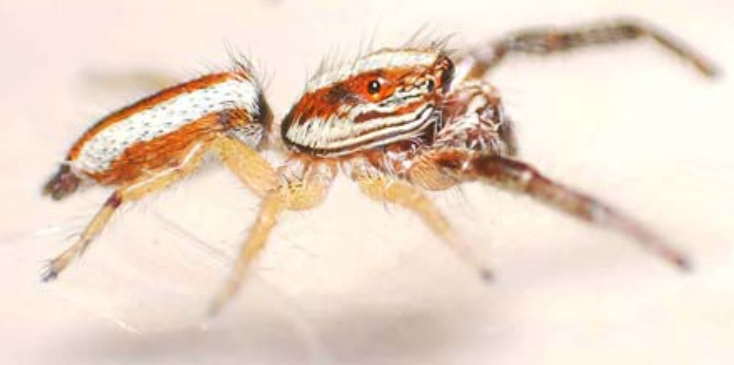

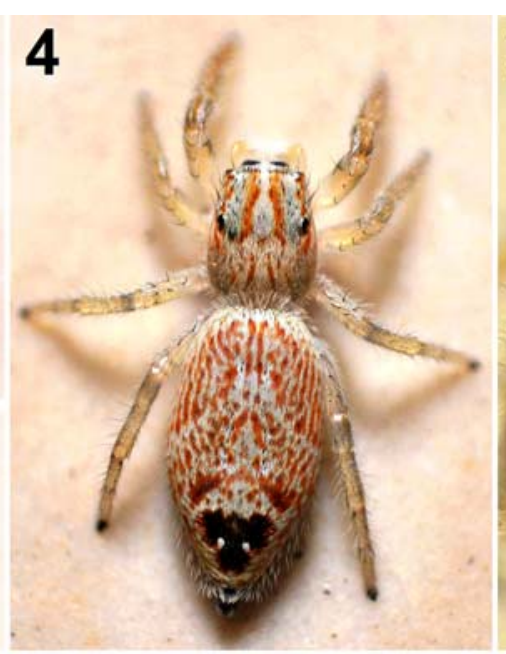

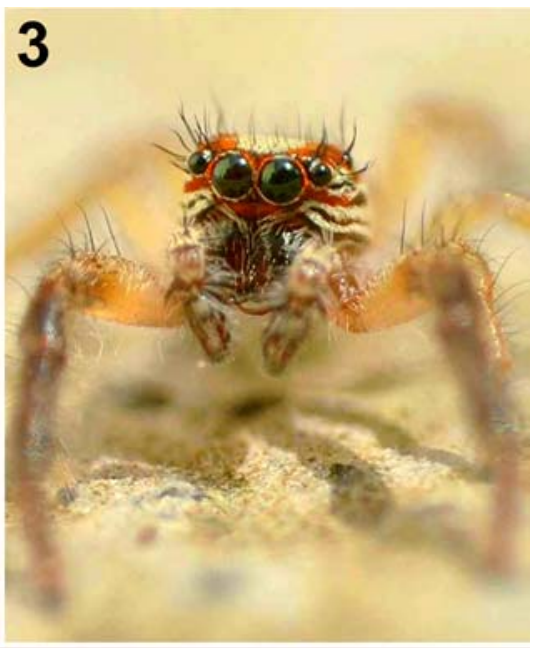

5

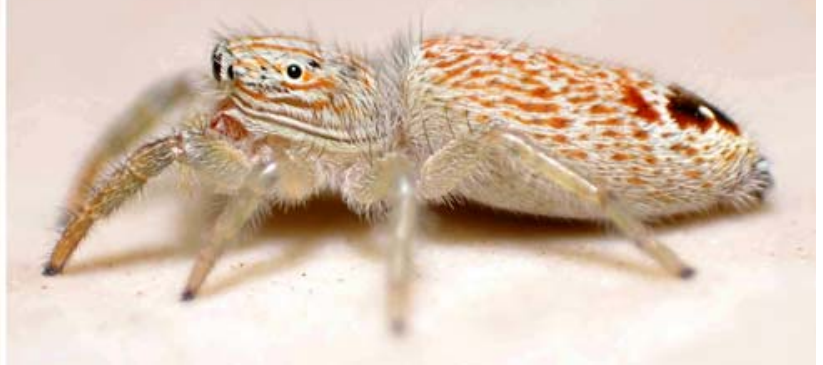

Figs 1-5 Rudakius ludhianaensis (Tikader, 1974), general appearance: 1 - male, dorsal view; 2 - ditto, lateral view; 3 - ditto, front view; 4 - female, dorsal view; 5 - ditto, lateral view.

Рис. 1-5 Rudakius ludhianaensis (Tikader, 1974), общий вид: 1 - самец, вид сверху; 2 - тоже, вид сбоку; 3 - тоже, вид спереди; 4 - самка, вид сверху; 5 - тоже, вид сбоку.

lection of John T.D. Caleb (Kolkata, West Bengal, India); MMUE - Manchester Museum of the University of Manchester, UK (curator: Dmitri V. Logunov); NIBGE National Institute for Biotechnology and Genetic Engineering, Faisalabad, Pakistan; NZC-ZSIK - National Zoological Collections, Zoological Survey of India, Kolkata (curator: Shelley Acharya); PAA - Personal collection of Pir Asmat Ali (Swabi, Pakistan); SRC-ZSIC - Southern Regional Centre, Zoological Survey of India, Chennai (curator: Babu Rajappa); ZMUM - Zoological Museum of the Moscow State University, Moscow, Russia (curator: Kirill G. Mikhailov).

\section{Taxonomy}

Rudakius Prószyński, 2016 1885.

Type species: Menemerus cinctus O. Pickard-Cambridge,

\section{Rudakius ludhianaensis (Tikader, 1974)}

Figs 1-29, Map.

Marpissa ludhianaensis Tikader, 1974: 205, figs 1-3 (D ${ }^{7}+$; holotype + in ZSIK, examined); Brignoli, 1983: 630, 642.

Phlegra citri Sadana, 1980: 229, figs 1-5 (D ${ }^{7}+$ ). Synonymized with Pseudicius ludhianaensis by Nenilin [1984b].

Pseudicius ludhianaensis: Nenilin, 1984a: 6; 1984b: 1178.
Marpissa endenae Biswas et Biswas, 1992: 391, figs. 23-25 (D $\odot$; holotype $\rightarrow$ in ZSIK, examined). Syn.n.

Pseudicius admirandus Logunov, 2007: 21, figs. 1-5 (D ${ }^{7}+$; holotype $\sigma^{7}$ in ZMUM, not examined). Syn.n.

Rudakius ludhianaensis: Prószyński, 2016: 25.

TYPE MATERIAL. Marpissa ludhianaensis Tikader, 1974: Holotype + (NZC-ZSIK) from India, Punjab, Ludhiana, the Punjab Agriculture University compound, 14.05.1972, G.L. Sadana. PARATYPES: $3 \sigma^{7} \sigma^{7}, 8$ o 8 \& 1 subadult $\sigma^{7}$ (NZC-ZSIK), together with the holotype. - Marpissa endenae Biswas et Biswas, 1992: Holotype + (NZC-ZSIK-5385/18) from India, West Bengal, Eden Garden, 15.07.1985, Kajal Biswas. Paratypes: 1 ㅇ, 1 subadult + (NZC-ZSIK-5386/18), together with the holotype.

OTHER MATERIAL. INDIA: $1 \sigma^{7}, 1$ ( 1 (SRC-ZSIC-I/SP, 32, 33), Tamil Nadu, Chennai, Thirumullaivoyal, Araabath Lake (13. $\left.125101^{\circ} \mathrm{N}, 80.135654^{\circ} \mathrm{E}\right)$, leaves of Mangifera tree, $21.73 \mathrm{~m}$ a.s.1., 10.10.2013, J. Caleb; $2 \sigma^{7} \sigma^{7}, 1$ (SRC-ZSIC-I/SP, 29-31), the same locality, 25.06.2016, J. Caleb; $1 \mathrm{O}^{7}$ (JCPC), the same locality, 18.08.2013, J. Caleb; $1 \sigma^{7}$ (JCPC), the same locality, 10. 10.2013, J. Caleb; $2 \sigma^{\top} \sigma^{\top}, 3$ sub-adults (JCPC), the same locality, 25.06.2016, J. Caleb; 1 ơ, 1 \& (GJSP, 834811A), Gujarat, Dharampur, nr. Shankar waterfall $\left(20.492644^{\circ} \mathrm{N}, 73.373822^{\circ} \mathrm{E}\right), 298.57 \mathrm{~m}$ a.s.l., 18.09.2014, D.A. Prajapati. - PAKistan: 1 o' (PAA, \#2016-08540), Khyber Pakhtunkhwa, Mardan, Takht Bhai, maize crop fields $\left(34.287^{\circ} \mathrm{N}, 71.951^{\circ} \mathrm{E}\right), 460 \mathrm{~m}$ a.s.1., 13.08.2016, P.A. Ali; 1 우 (PAA, \#2016-08-541), Khyber Pakhtunkhwa, Mardan, Takht Bhai $\left(34.289^{\circ} \mathrm{N}, 71.954^{\circ} \mathrm{E}\right), 462 \mathrm{~m}$ a.s.1., 13.08.2016, P.A. Ali; $1 \sigma^{\top}, 1$ 우 (PAA, \#2016-08-560, \#2016-08-561), Khyber Pakhtunkhwa, Malakand, Dargai $\left(34.513^{\circ} \mathrm{N}, 71.881^{\circ} \mathrm{E}\right), 644-648 \mathrm{~m}$ a.s.1., 28.08.2016,

P.A. Ali; $1 \sigma^{7}, 1$ 오 (PAA, \#2017-07-038, \#2017-07-037), Khyber Pakhtunkhwa, Chitral, Chitral City $\left(35.756^{\circ} \mathrm{N}, 71.790^{\circ} \mathrm{E}\right)$, bark of 

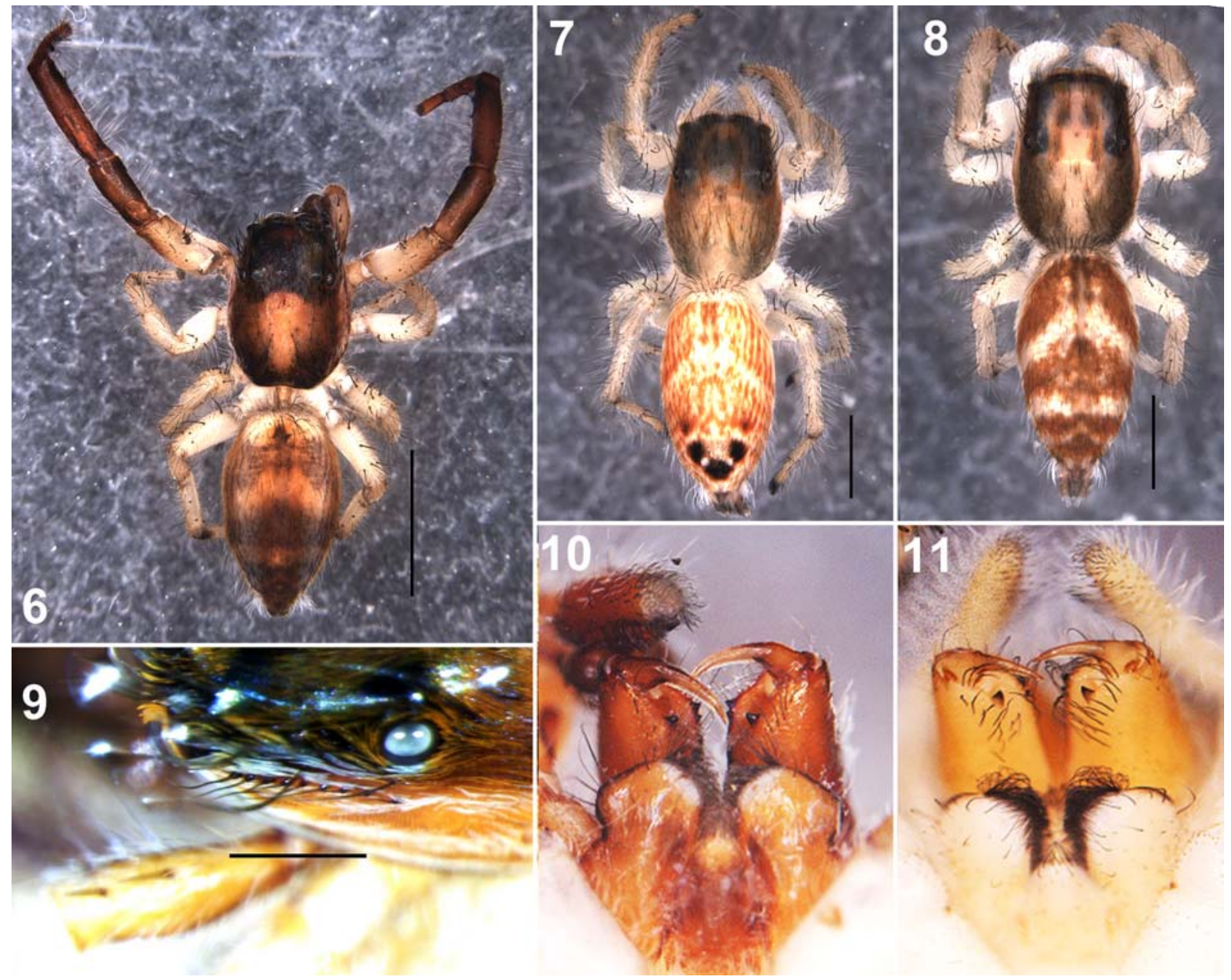

Figs 6-11. Rudakius ludhianaensis (Tikader, 1974): 6 - male, dorsal view; 7 - female, dorsal view; 8 - subadult male, dorsal view; 9 - male carapace, dorso-lateral view; 10 - male chelicerae, ventral view; 11 - female chelicerae, ventral view. Scale bars: (6) $2 \mathrm{~mm}$; (7, 8) $1 \mathrm{~mm}$; (9) $0.5 \mathrm{~mm}$.

Рис. 6-11. Rudakius ludhianaensis (Tikader, 1974): 6 - самец, вид сверху; 7 - самка, вид сверху; 8 - ювенильный самец, вид сверху; 9 - карапакс самца, вид сбоку-сверху; 10 - хелицера самца, вид снизу; 11 - хелицера самки, вид снизу. Масштаб: (6) 2 мм; (7, 8) 1 мм; (9) 0.5 мм.

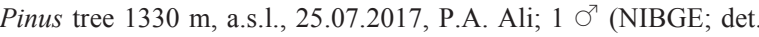
G.A. Blagoev), Punjab, Jaranwala, Maly da kot, $\left(31.3333^{\circ} \mathrm{N}\right.$, 73.4167 ${ }^{\circ}$ ), $161 \mathrm{~m}$ a.s.1., 17.07.2010, S. Akhtar; 1 ( (NIBGE; det. G.A. Blagoev), Punjab, D.G. Khan, Fort Minro $\left(29.9167^{\circ} \mathrm{N}\right.$, $\left.69.9667^{\circ} \mathrm{E}\right), 1850 \mathrm{~m}$ a.s.1., 18.05 .2010 , S. Akhtar; $1 \mathrm{O}^{\gamma}, 1$ immature (NIBGE; det. G.A. Blagoev), Punjab, Nankana Sahib $\left(31.45^{\circ} \mathrm{N}\right.$, $73.7^{\circ} \mathrm{E}$ ), $193 \mathrm{~m}$ a.s.1., 28.05.2010, S. Akhtar; 1 ㅇ (NIBGE; det. G.A. Blagoev), Punjab, Faisalabad, Manawala $\left(31.45^{\circ} \mathrm{N}\right.$, $73.1333^{\circ} \mathrm{E}$ ), $186 \mathrm{~m}$ a.s.1., 29.04 .2010 , S. Akhtar; 1 (MMUE; det. D.V. Logunov), (no exact locality) imported to the UK in the box of guava fruits imported from Pakistan, 19.01.2012 (received from the Food and Environment Research Agency, York, UK; FER 21200775); $2 \sigma^{7} \sigma^{7}$ (MMUE; det. D.V. Logunov), Lahore, Eucalyptus trunk, leaves of Plumeria and jasmine, 28.04.2013, G. Rasool.

DIAGNOSIS. The males of this species can be easily distinguished from the congeneric males by the uniquely thick embolus having as if the tegulum being extended to its sub-apical region (the embolus is long and free in all other congeners); the cleft between the embolus and a retrolateral hump of the tegulum narrow (Figs 13, 15, 26, 27). The females can be distinguished from all the congeners, except for $R$. afghanicus, by the elongated spermathecae (Fig. 29). By their colour pattern and the internal structure of the copulatory organs, the females of $R$. ludhianaensis are very similar to those of $R$. afghanicus, but can be separated by the shape of the median septum widening medially (wider anteriorly and narrows posteriorly near the copulatory opening in R. afghanicus) (cf. Figs 22, 28 with fig. 37 in Andreeva et al., 1984); but see also comments below under 'Remarks'.

DESCRIPTION. Male (paratype, Figs 12-14). Total length: 4.75; carapace: 2.17 long, 1.66 wide; abdomen: 2.56 long, 1.49 wide. Carapace brownish, covered with pale hairs; eye field dark brown. Posterior eyes surrounded by black patches (Fig. 12). Eye measurements: AME 0.39, ALE 0.21, PME 0.06, PLE 0.19, AER 1.25, PER 1.40, EFL 0.91. Clypeus height 0.05. Sternum oval, yellowish. Chelicerae yellow-brown, with two teeth on the promargin and one tooth on the retromargin; labium and maxillae light brown. Legs yellowish, except brownish patellae, tibiae, metatarsi and tarsi of leg I; leg I robust (Figs 12, 17). Leg measurements: I $5.03(1.45,0.88,1.42,0.90,0.38)$; II 3.29 (1.00, 


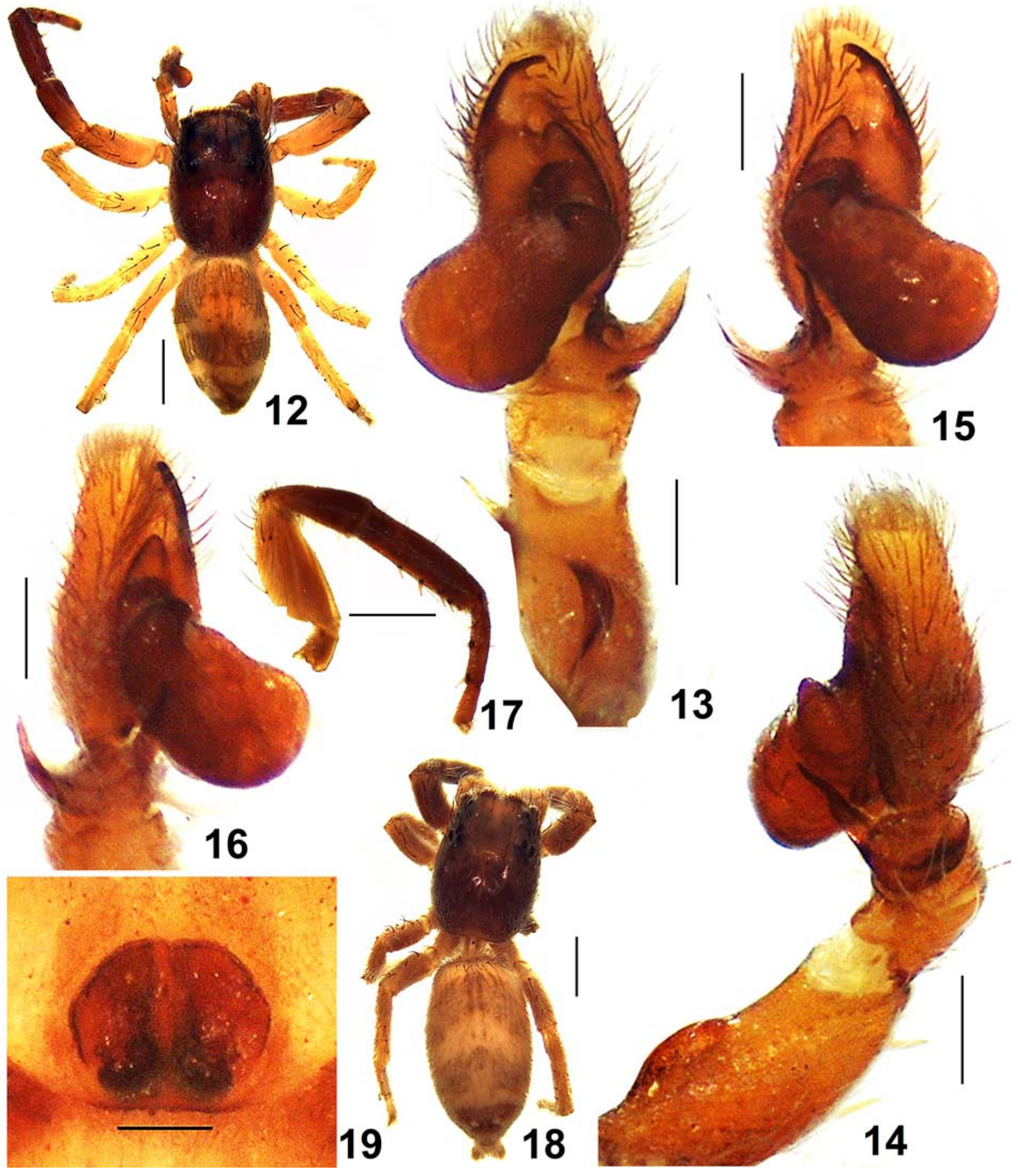

Figs 12-19. Rudakius ludhianaensis (Tikader, 1974), the types of Marpissa ludhianaensis, paratype male (12-14), the paratype male originally illustrated by Tikader in which left palp is missing (15-17) and holotype female (18-19): 12, 18 - general appearance, dorsal view; 13 - left palp, ventral view; 14 - ditto, retrolateral view; 15 - right palp, ventral view; 16 - ditto, retrolateral view; 17 - left leg I, prolateral view; 19 - epigyne, ventral view. Scale bars: $(12,17,18) 1 \mathrm{~mm} ;(13-16,19) 0.25 \mathrm{~mm}$.

Рис. 12-19. Rudakius ludhianaensis (Tikader, 1974), типы Marpissa ludhianaensis, самец-паратип (12-14), самец-паратип, которого иллюстрировал Тикадер, и у которого нет левой пальпы (15-17) и самка-голотип (18-19): 12, 18 - общий вид сверху; 13 левай пальпа, вид снизу; 14 - тоже, вид сбоку-сзади; 15 - правая пальпа, вид снизу; 16 - тоже, вид сбоку-сзади; 17 - левая нога I, вид спереди-сбоку; 19 - эпигина, вид снизу. Масштаб: $(12,17,18) 1$ мм; $(13-16,19) 0,25$ мм. 

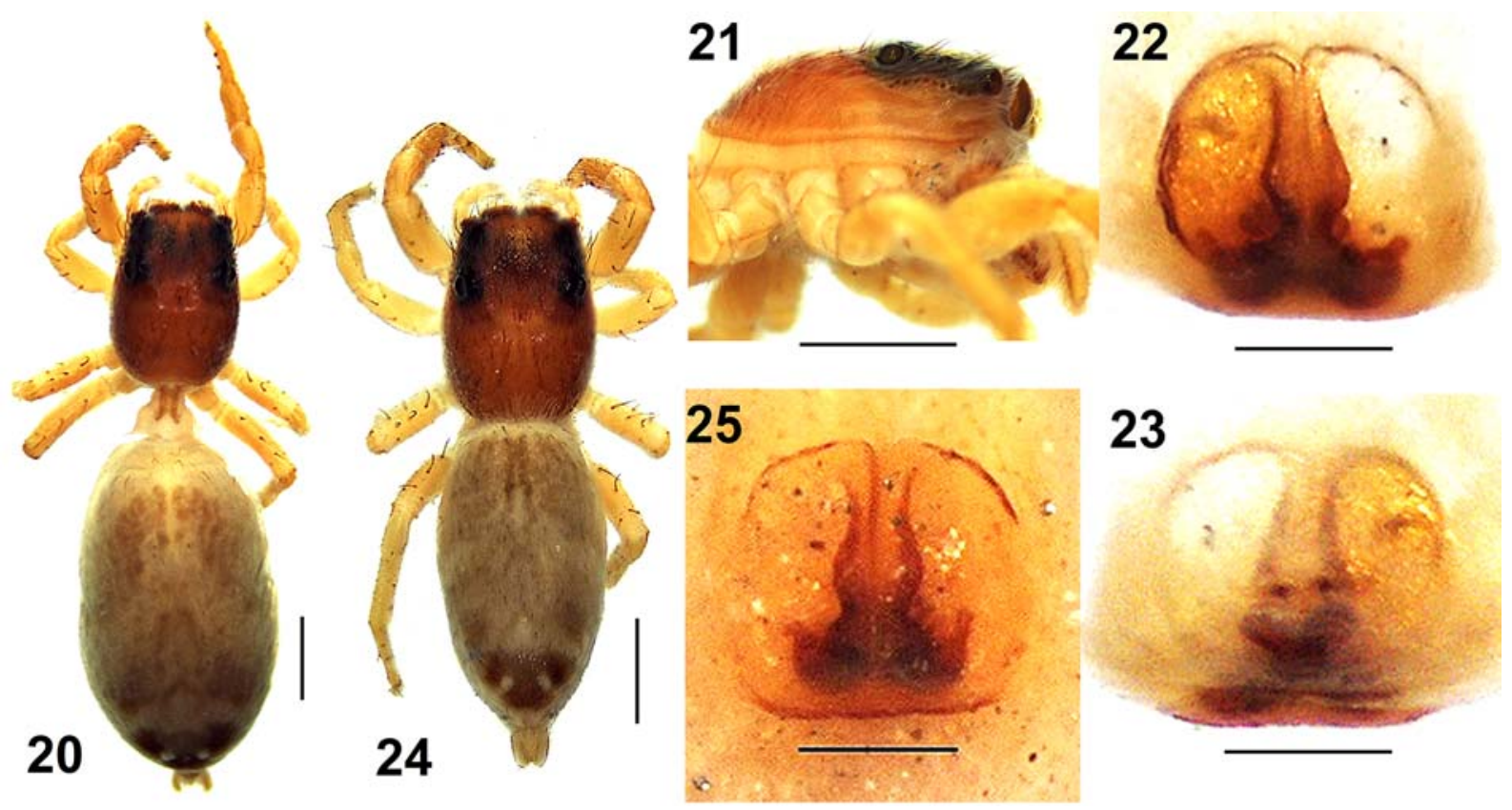

Figs 20-25. Rudakius ludhianaensis (Tikader, 1974), the types of Marpissa endenae Biswas et Biswas, 1992, the holotype female (20-23) and the paratype female (24-25): 20, 24 - dorsal view; 21 - carapace, lateral view; 22,25 - epigyne, ventral view; 23 spermathecae, dorsal view. Scale bars: $(20,21,24) 1 \mathrm{~mm} ;(22,23,25) 0.25 \mathrm{~mm}$.

Pис. 20-25. Rudakius ludhianaensis (Tikader, 1974), типы Marpissa endenae Biswas et Biswas, 1992, самка-голотип (20-23) и самка-паратип (24-25): 20, 24 - вид сверху; 21 - головогрудь, вид сбоку; 22, 25 - эпигина, вид снизу; 23 - сперматека, вид сверху. Масштаб: $(20,21,24) 1$ мм; $(22,23,25) 0,25$ мм.
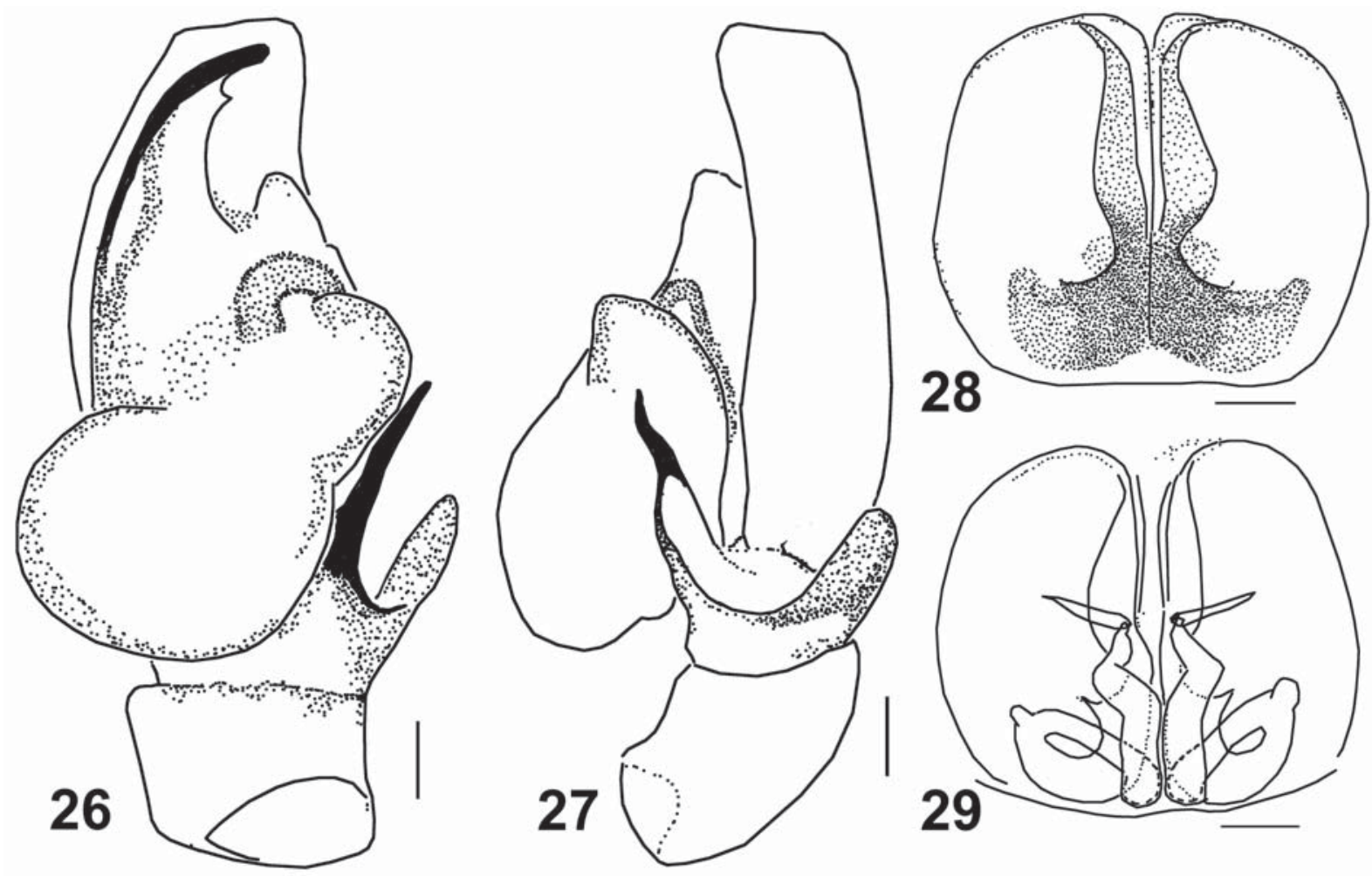

Figs 26-29. Rudakius ludhianaensis (Tikader, 1974) from India, Tamil Nadu, Chennai: 26 - left palp, ventral view; 27 - ditto, retrolateral view; 28 - epigyne, ventral view; 29 - spermathecae, dorsal view. Scale bars: (26-29) $0.1 \mathrm{~mm}$.

Рис. 26-29. Rudakius ludhianaensis (Tikader, 1974) из Индии, Тамил Наду, Хеннай: 26 - левая пальпа, вид снизу; 27 - тоже, вид сбоку-сзади; 28 - эпигина, вид снизу; 29 - сперматека, вид сверху. Масштаб: (26-29) 0,1 мм. 


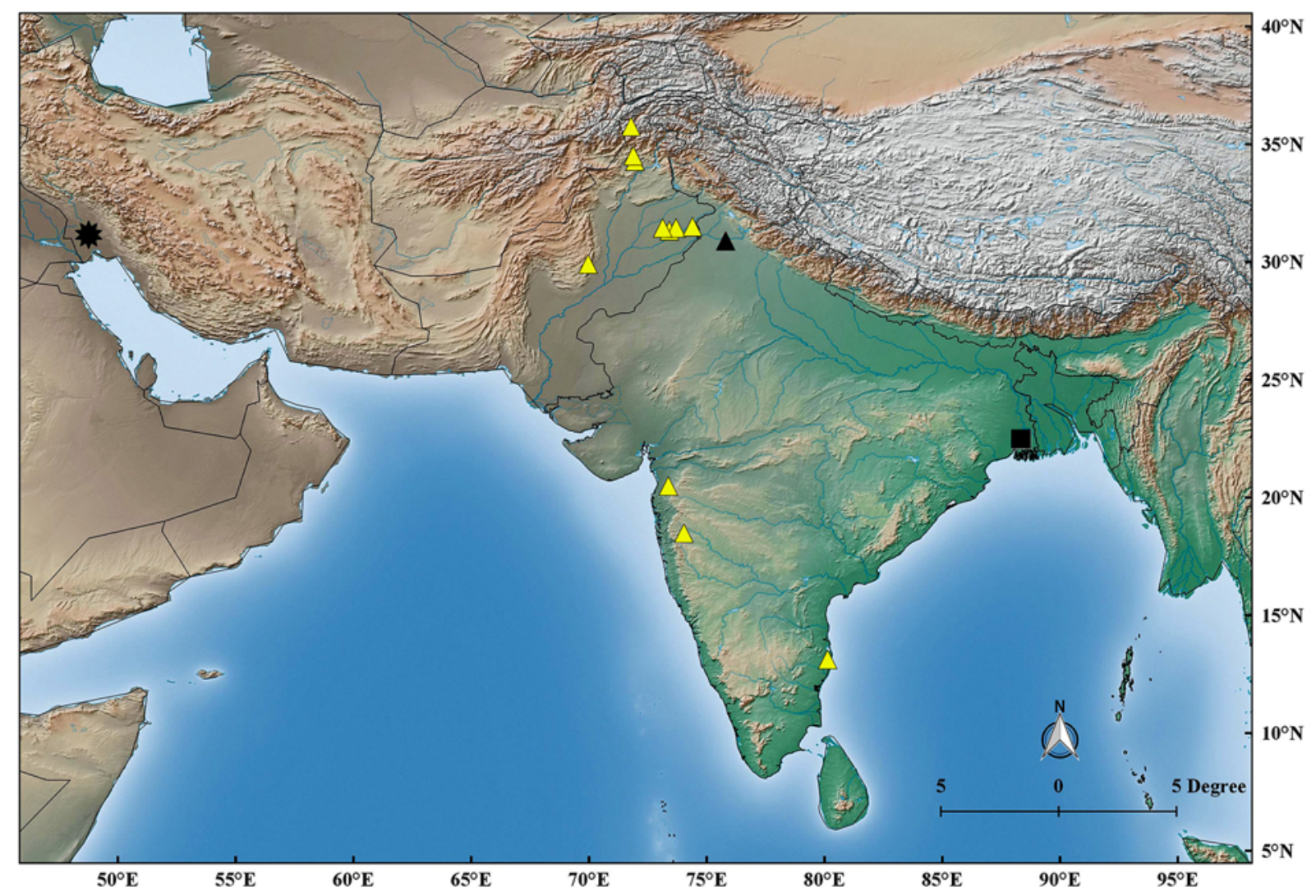

Map. Collecting localities of Rudakius ludhianaensis (Tikader, 1974) (yellow triangles), with its type locality indicated with a black triangle. Black asterisk and square show the type localities of Pseudicius admirandus Logunov, 2007 and Marpissa endenae Biswas et Biswas, 1992 respectively.

Карта. Точки находок Rudakius ludhianaensis (Tikader, 1974) (желтые треугольники), с типовым локалитетом помеченным черным треугольником. Черные звездочка и квадрат отмечают типовые локалитеты Pseudicius admirandus Logunov, 2007 и Marpissa endenae Biswas et Biswas, 1992 соответственно.

$0.67,0.70,0.58,0.34) ;$ III $3.37(1.08,0.57,0.59,0.70$ $0.43)$; IV $4.24(1.42,0.65,0.92,0.84,0.43)$. Leg formula: 1432. Leg spination: femora I 0500, II 0500, III 0700, IV 0500; patellae III 0010; tibiae I 1003, II 1001, III 3012, IV 2013; metatarsi I 0004, II 0004, III-IV 2024; tarsi I-IV 0000. Abdomen brownish, with a mid-longitudinal broad orange band; two yellowish transverse stripes (Fig. 12). Spinnerets yellowish. Palps yellowish, covered with pale white hairs; embolus thick, RTA branching; the ventral branch long and slender, the dorsal branch is shorter and flattened (Figs 13, 14).

Female (holotype, Figs 18, 19). Total length: 5.48; carapace: 2.32 long, 1.79 wide; abdomen: 3.16 long, 1.77 wide Eye measurements: AME 0.46, ALE 0.21, PME 0.06, PLE 0.19, AER 1.35, PER 1.52, EFL 0.91. Clypeus height 0.09. Leg measurements: I 2.70 (1.23, 0.87, 0.85, 0.61, 0.34); II $3.33(1.40,0.74,0.67,0.51,0.31)$; III $3.61(1.14,0.65,0.64$, $0.78,0.40)$; IV $4.50(1.40,0.76,0.96,0.85,0.43)$. Leg formula: 4321. Leg spination: femora I 0400, II 0500, III 0700, IV 0500; patellae I-IV 0000; tibiae I 1003, II 1001, III 1013, IV 2013; metatarsi I 0004, II 1004, III-IV 3024; tarsi I-IV 0000. Female similar to male but differs only in the posterior marking of the abdomen (Fig. 18). Epigyne with large, oval fossae separated by the median septum; copulatory openings lie at the posterior medial region (Fig. 19).
LIVE COLORATION. MALE. Carapace reddish brown, with a mid-longitudinal broad white stripe and white lateral margins (Fig. 1). Clypeus covered with reddish hairs and thin transverse white stripes (Fig. 3). Abdomen brownish, with a mid-dorsal reddish brown band and alternating white and reddish bands (Figs 1, 2). Female. Carapace covered with white hairs and orange, longitudinal stripes along the eye field and posterior slope of carapace. Abdomen covered white hairs and thin reticulations of orange hairs. Posterior end with a black triangular region and a pair of white spots (Fig. 4). Subadult males are slightly different in their colour pattern and resemble the females (Fig. 8).

HABITATS. Newly collected material suggests that this species can be found across various altitudes, ranging from near the sea level in eastern India $(11 \mathrm{~m}$ a.s.1.) to higher montane regions (1850 m a.s.1.) in northern Pakistan. It was collected from a variety of plants and trees (Mangifera, Pinus, maize, Eucalyptus, Plumeria and jasmine). Yet, one specimen was found in guava fruits exported from Pakistan to the UK (D.V. Logunov, pers. comm.; the material is deposited at the MMUE, see above under 'Other material').

REMARKS. Pseudicius admirandus Logunov, 2007 was described in detail from both sexes (the holotype male and the paratype female collected from SW Iran [Logunov, 2007]. While examining the type series of $R$. ludhianaensis kept in 
NZC, ZSI, it has become evident that $P$. admirandus is identical to the former species by the conformation of its copulatory organs: viz., the male palp with thick, shorter and blunt embolus; the branched RTA with longer, wavy and slender ventral branch and shorter, flattened dorsal branch; the epigyne with long median septum, narrow anteriorly and widening medially; and the elongate spermathecae lying along the axis of the median septum (cf. Figs 13, 14, 19, 2629 with figs 1-4 in Logunov [2007]). Another species, Marpissa endenae Biswas et Biswas, 1992 was described on the basis of the holotype and paratype females from Eden Garden of Kolkata (India). The species unambiguously matches $R$. ludhianaensis by its dorsum colour pattern, with a pair of white spots on the dark brown triangular background at the posterior region, and the conformation of the female copulatory organs (see the characters mentioned above) (cf. Figs 18-19 with Figs 20-25). Based on these observations, it is hence safe to conclude that both the aforementioned species names are to be considered the junior synonyms of $R$. $l u$ dhianaensis.

The spermathecae of $R$. ludhianaensis and $R$. afghanicus are very similar and it is possible that the females hitherto attributed to $R$. afghanicus actually belong to $R$. ludhianaensis, being misidentified and mismatched with the corresponding males. The only difference observed in the epigynal structure is the shape of the median septum, which is narrower anteriorly and widens medially in $R$. ludhianaensis, whereas it is wide anteriorly and narrows posteriorly in $R$. afghanicus. The matter needs a special attention in the future, when more samples of $R$. afghanicus with both sexes collected together are available.

DISTRIBUTION. SW Iran, Pakistan, India (Map).

Acknowledgements. We are grateful to Dr Kailash Chandra, Director of the Zoological Survey of India, Kolkata for the immense encouragement to carry out the work and permitting the examination of the types. Our sincere thanks go to Dr Shelley Acharya, the Officer-in-Charge of the Division of Arachnology (ZSI) for her kind support and to $\mathrm{Mr}$ Chandan Bera who extended his help in sorting out and loaning the type material for the present study. D.A. Prajapati thanks Dr P.A. Sebastian for his encouragement and for providing the necessary facilities for the present study. John Caleb thanks Dr K. Ilango, Ex-Officer-in-charge of the Southern Regional Centre (Zoological Survey of India, Chennai) for allowing him to use the stereomicroscope facility and to deposit the studied specimens. Thanks go to Dr Krushnamegh Kunte, Lab 8, National Centre for Biological Sciences (NCBS), for his generous support and allowing us to use the stereomicroscope facility. Thanks also go to Dr Galina Azarkina (Novosibirsk, Russia) for her kind help in translating the Russian text from the publications by A.B. Nenilin. Anuradha Joglekar (Mumbai, India) is thanked for the help in preparation of the distribution map. We would like to extend our warm thanks to Muhammad Ashfaq and Gergin Blagoev (Canada) for providing us with original information on the distribution of $P$. ludhianaensis in Paki- stan. Pir Asmat Ali acknowledges the Grant of Women University, Swabi for exploration work of the arachnid fauna in Swabi district, Pakistan. Finally, sincere thanks go to Dr Dmitri Logunov (Manchester, UK) for providing valuable information and data on the distribution of $P$. ludhianaensis and for all the critical comments/suggestions that helped us to improve the ms.

\section{References}

Andreeva E.M., Hęciak S., Prószyński J. 1984. Remarks on Icius and Pseudicius (Araneae, Salticidae) mainly from central Asia // Annales Zoologici, Warszawa. T.37. P.349-375.

Biswas B., Biswas K. 1992. Araneae: Spiders. State Fauna Series 3: Fauna of West Bengal. Vol.3. P.357-500.

Brignoli P.M. 1983. A catalogue of the Araneae described between 1940 and 1981. Manchester University Press. 755 pp.

Caleb J.T.D. 2016. New data on the jumping spiders (Araneae: Salticidae) from India // Arthropoda Selecta. Vol.25. No.3. P.271-277.

Caleb J.T.D., Prajapati D.A., Rameshwar Maheshwari N., Sanap R.V. 2017. Redescription and synonymy of Stenaelurillus arambagensis (Biswas et Biswas, 1992) comb.n. (Araneae: Salticidae) // Arthropoda Selecta. Vol.26. No.2. P.119-123.

He S., Hu J.L. 1999. A new species of the genus Pseudicius from Yunnan Province, China (Araneae: Salticidae) // Acta Arachnologica Sinica. Vol.8. No.1. P.32-33.

Koch C.L. 1846. Die Arachniden. Nürnberg: J.L. Lotzbeck. Dreizehnter Band. 234 S.; Vierzehnter Band. $88 \mathrm{~S}$.

Logunov D.V. 2007. A new species of the genus Pseudicius Simon 1885 (Araneae: Salticidae) from SW Iran // Acta Arachnologica. Vol.56. No.1. P.21-23.

Nenilin A.B. 1984a. [Materials on the fauna of the spider family Salticidae of the USSR. I. Catalog of the Salticidae of Middle Asia] // Utotchkin A.S. (ed.). Fauna and Ecology of Arachnids, Perm University Press. P.6-37 [in Russian].

Nenilin A.B. 1984b. [On the taxonomy of spiders of the family Salticidae of the fauna of the USSR and adjacent countries] // Zoologicheskii Zhurnal. Vol.43. P.1175-1180 [in Russian, with English summary].

Pickard-Cambridge O. 1885. Araneidea. In: Scientific results of the second Yarkand mission; based upon the collections and notes of the late Ferdinand Stoliczka, Ph. D. Government of India, Calcutta, 115 pp., 2 pls.

Prószyński J. 1992. Salticidae (Araneae) of the Old World and Pacific Islands in several US collections // Annales Zoologici PAN. T.44. P.87-163.

Prószyński J. 2016. Delimitation and description of 19 new genera, a subgenus and a species of Salticidae (Araneae) of the world // Ecologica Montenegrina. Vol.7. P. 4-32.

Sadana G.L. 1980. A new Indian species of Phlegra Simon (Araneida: Salticidae) // Entomologist's Monthly Magazine. Vol.115. P.229-230.

Tikader B.K. 1974. Studies on some jumping spiders of the genus Marpissa from India (family-Salticidae) // Proceedings of the Indian Academy of Science. Vol.79(B). P.204-215.

WSC 2018. World Spider Catalog. Natural History Museum Bern; online at: http://wsc.nmbe.ch, version 19.5, (accessed on 03 December 2018).

Responsible editor D.V. Logunov 